TOMASZ RACHWAL

\title{
Kształtowanie się wiodących zakładów przemysłu cukierniczego w Krakowie do 1950r.
}

W okresie polski międzywojennej przemysł cukierniczy był jedną z najlepiej rozwiniętych branż przemysłu w Krakowie. Do największych krakowskich fabryk wyrobów cukierniczych w tym czasie należały zakłady „A. Piaseckiego”, „Sucharda”, „Pischingera”. Z tych 3 zakładów oraz z majątku zlikwidowanych fabryk „Helia” i "Krysztal” w 1951r. utworzono funkcjonujące do dziś Zakłady Przemysłu Cukierniczego „Wawel” S.A., jako jedno z największych przedsiębiorstw tej branży w Polsce. Przedmiotem niniejszej pracy będzie analiza procesu kształtowania się wiodących zakładów przemysłu cukierniczego w Krakowie do 1950r. Główna uwaga zostanie zwrócona na problem, jak zakłady te zachowywały się w warunkach korzystnej koniunktury wzrostu gospodarczego, w latach wielkiego kryzysu gospodarczego, w warunkach okupacji i pierwszych latach powojennych. Poszczególne okresy charakteryzowały się odmiennymi uwarunkowaniami dla kształtowania się analizowanych firm, a wydaje się, że wiele podobnych sytuacji z lat pogłębiającego się kryzysu gospodarczego lat 30 . można zauważyć obecnie, a latach transformacji gospodarki.

Za początek przemysłu cukierniczego w Krakowie należy uznać działalność cukiernika Adama Piaseckiego, który w 1910r. rozpoczął produkcję wyrobów czekoladowych na skalę przemysłową. Początki jego działalności gospodarczej sięgają jednak jeszcze 1898r., kiedy założył własną pracownię cukierniczą i sklep przy ul. Długiej 20 (od 1901r. - przy ul. Długiej 10) w Krakowie, zatrudniając początkowo 5 pracowników (tab.1, ryc. 1). Dzięki wysokiej jakości wyrobów firma zdobywała coraz szerszą klientelę i rozwijała się szybko, co umożliwiło w 1904r. otwarcie filii cukierni w ówczesnym Hotelu Drezdeńskim przy ul. Floriańskiej 2. [Polski słownik..., 1980]. Należy zaznaczyć, że przy ulicy Floriańskiej (pod nr 45) Piasecki miał bardzo silną konkurencję - założoną w 1895r. cukiernię Jana Michalika (zwaną Cukiernią Lwowska), produkującą bardzo dobre wyroby cukiernicze i czekoladowe, a nawet kakao w proszku. W szczytowym okresie Cukiernia Lwowska zatrudniała 43 pracowników i sprzedawała swoje wyroby nie tylko detalicznie, ale także odbiorcom hurtowym. Sławę i klientów przynosił cukierni Jana Michalika także występujący tam w latach 1905-1912 kabaret literacki „Zielony Balonik”. W tym czasie funkcjonowało w Krakowie także kilka innych, większych warsztatów cukierniczych, m.in. Józefa Siermontowskiego, Leonarda Malika, Romualda Pieczarka, sprzedawane były także wyroby $\mathrm{z}$ innych, znanych cukierni założonych wcześniej $\mathrm{w}$ innych miastach galicyjskich [Weber, 1970]. Tym bardziej na uwagę zasługuje więc ekspansja firmy Piaseckiego.

\footnotetext{
${ }^{1}$ Używane tu nazwy firm są skrótowe ( ze względu na liczne zmiany form działalności oraz zmiany nazw firm) - szczegóły w dalszej części opracowania.
} 
Tab. I. Poziom i dynamika zatrudnienia w pracowni cukierniczej A.Piaseckiego w latach 1898-1907.

\begin{tabular}{|c|c|c|c|}
\hline \multirow[b]{2}{*}{ Rok } & \multirow[b]{2}{*}{ Zatrudnienie } & \multicolumn{2}{|c|}{ Dynamika (\%) } \\
\hline & & $1898 r .=100$ & $\begin{array}{c}\text { rok po- } \\
\text { przed.=100 }\end{array}$ \\
\hline 1898 & 5 & 100 & - \\
\hline 1904 & 30 & 600 & 600 \\
\hline 1907 & 45 & 900 & 150 \\
\hline
\end{tabular}

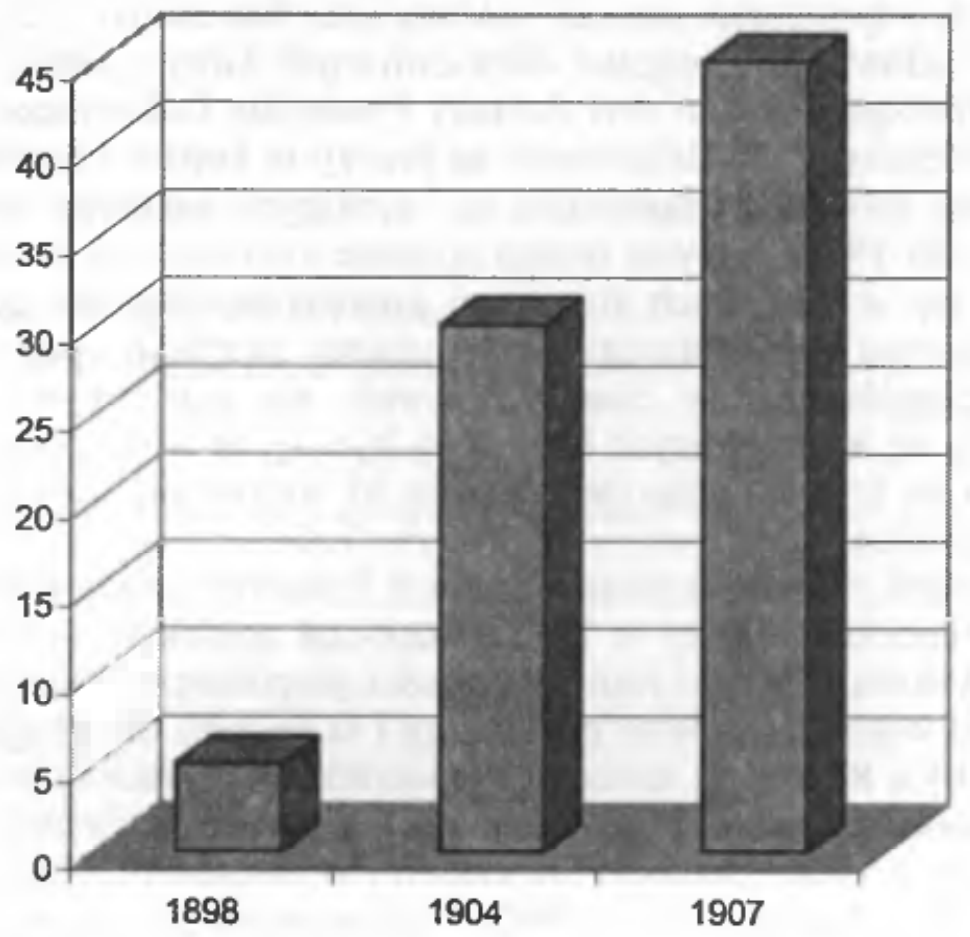

Ryc. 1. Zmiany poziomu zatrudnienia w pracowni cukierniczej A.Piaseckiego w latach 1898-1907.

W 1907 roku w pracowni przy ul. Długiej 10 A. Piasecki zainstalował pierwsze maszyny do wyrobu czekolady twardej. W celu sprostania coraz większym zamówieniom zatrudnienie wzrosło w porównaniu do 1898 r. 9-krotnie, do ok. 45 osób.

Wyjątkowe powodzenie i rosnąca sława wyrobów firmy Piaseckiego, wzrastające zapotrzebowanie na produkty cukiernicze i czekoladowe wraz $\mathrm{z}$ rozwojem liczby ludności miasta i tym samym konieczność sprostania coraz większym zamówieniom, skłoniły go do rozpoczęcia w 1910 r. produkcji fabrycznej na skalę przemysłową. Za zaoszczędzone pie- 
niądze kupił więc parcelę z niewielkim parterowym budynkiem przy ul. Szlak 26. Po zaadaptowaniu budynku na cele fabryczne, rozpoczęto produkcję, zatrudniając w nowej fabryce 22 osób (tab.2, ryc.2). Dzięki kredytowi udzielonemu mu w 1911r. przez Krajową Komisję dla Spraw Przemysłowych Piasecki zakupił nowe maszyny w firmie Lehmann z Drezna, co pozwoliło mu na trzykrotne zwiększenie produkcji do ok. 600-700 kg dziennie. Tajemnica sukcesu leżała $w$ bardzo dobrej jakości wyrobów ciągłym doskonaleniu i rozszerzaniu produkowanego asortymentu, dlatego Piasecki w 1911 r. zatrudnił w fabryce szwajcarskiego mistrza cukierniczego, który przez pół roku szkolił pracowników i jako kierownik produkcji wprowadzał nowe receptury. W 1912r. warsztat i cukiernia przy ul. Długiej 10 została sprzedana, a pracownicy przeniesieni do nowej fabryki. Rozpoczęte z rozmachem w $1911 \mathrm{r}$. inwestycje przekroczyły jednak moźliwości finansowe firmy, dlatego Piasecki zdecydował się na zaciągnięcie w 1913r. drugiej pożyczki, która pozwoliła na spłatę starych dhugów i dalsze inwestycje. Ciagłe inwestycje w maszyny i urządzenia do produkcji, spowodowały konieczność zakupu 2 sąsiednich parceli i wznoszenia dalszych zabudowań. W efekcie tych działań fabryka produkowała w 1914r. $1500 \mathrm{~kg}$ wyrobów dziennie. W produkowanym asortymencie było 13 gatunków czekolady nadziewanej, 11 twardej, 3 mlecznej, 18 gatunków karmelków twardych, nadziewanych i oblewanych czekoladą, galanteria czekoladowa, pralinki, marcepanki, alberty, biszkopty, herbatniki, krajanki, torciki i inne ciastka. Produkowano także śliwki i wiśnie w czekoladzie oraz różnego rodzaju figurki, cygara, papierosy wykonane z czekolady. Wszystkie wyroby miały atrakcyjne opakowania firmowe. Co pół roku wydawano atrakcyjne, kolorowe cenniki (katalogi) firmowe, propagujące nowości wprowadzone do produkcji.

$T a b$. 2. Poziom i dynamika zatrudnienia w fabryce czekolady A.Piaseckiego (przy ul. Szlak w Krakowie) w latach 1910-1920.

\begin{tabular}{|c|c|c|c|}
\hline \multirow{2}{*}{ Rok } & \multirow{2}{*}{ Zatrudnienie } & \multicolumn{2}{|c|}{ Dynamika (\%) } \\
\cline { 3 - 4 } & & $1910 \mathrm{r}=\mathbf{1 0 0}$ & $\begin{array}{c}\text { rok po- } \\
\text { przed.=100 }\end{array}$ \\
\hline 1910 & 22 & 100 & - \\
\hline 1911 & 68 & 309 & 309 \\
\hline 1912 & 75 & 341 & 110 \\
\hline 1913 & 98 & 445 & 131 \\
\hline 1914 & 124 & 564 & 127 \\
\hline 1919 & 90 & 409 & 73 \\
\hline 1920 & 100 & 455 & 111 \\
\hline
\end{tabular}


Rozszerzanie asortymentu produkcji wymagało także zmian w zatrudnieniu, które wzrosło od momentu uruchomienia fabryki prawie 6-krotnie i wynosiło w 1914r. 124 osób (nie licząc robotników sezonowych, których zatrudniano przed św. Bożego Narodzenia w ilości 20-50). Ponad 70\% załogi stanowiły kobiety, które pracowały głównie jako robotnice niewykwalifikowane, natomiast $5-12 \%$ stanowili młodociani, najczęściej uczniowie wspomnianej już szkoły cukierniczej, odbywający w fabryce praktykę zawodową. Zgodnie z porządkiem roboczym (regulaminem) młodociani do 16 roku życia musieli mieć zgodę rodziców (prawnych opiekunów), a do 14 roku życia, zgodnie z prawem, nie byli w ogóle przez Piaseckiego zatrudniani.

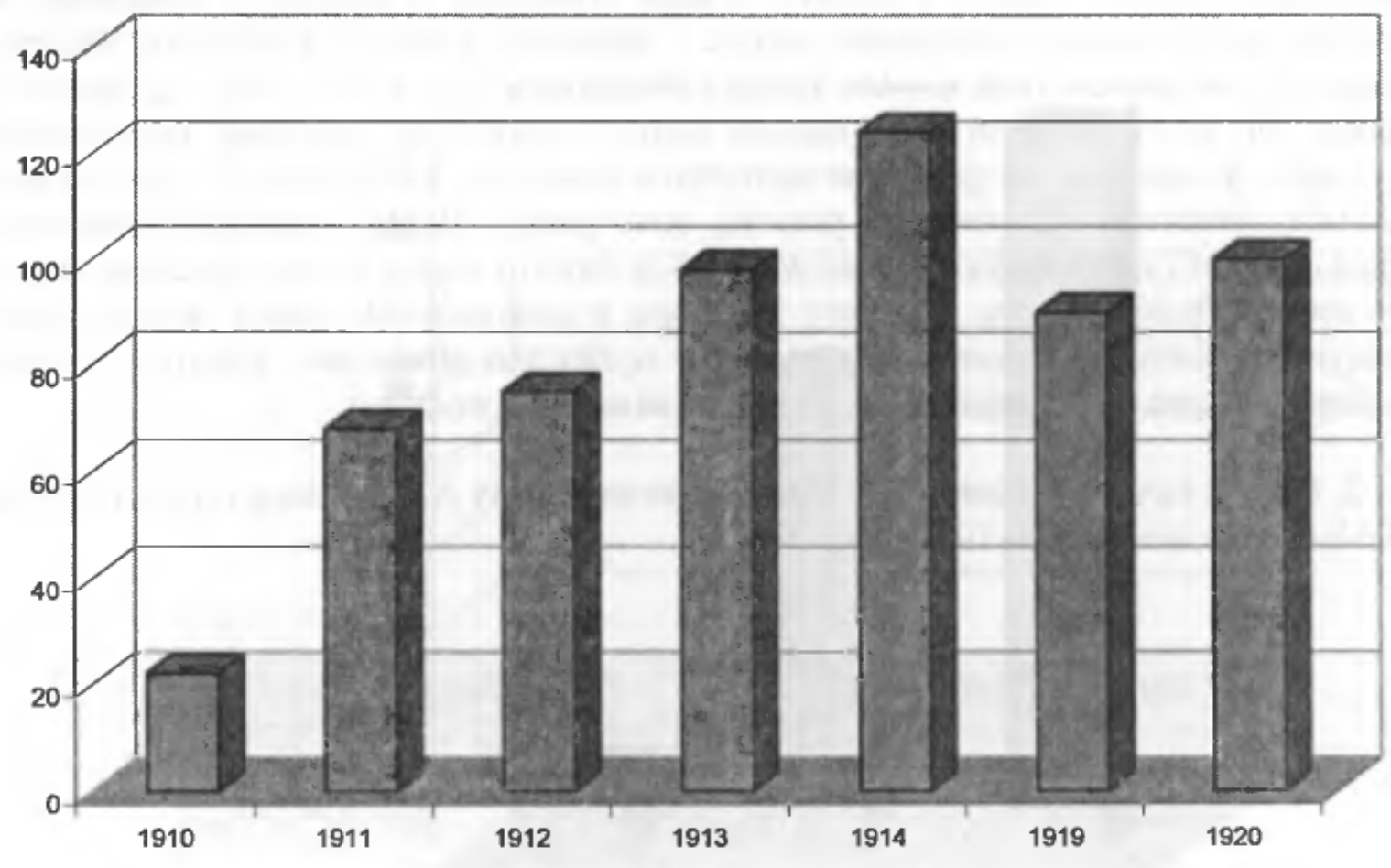

Ryc. 2. Zmiany poziomu zatrudnienia w fabryce czekolady A.Piaseckiego (przy ul. Szlak w Krakowie) w latach 1910-1920.

Produkcja opierała się na pracy majstrów i czeladników oraz pomocników i zawijaczek. Zarobki były zróżnicowane, najwięcej zarabiali majstrowie, którzy byli kierownikami działów (od 45-90 koron na tydzień), następnie czeladnicy (19-25 k), pomocnicy (12-18 k) i zawijaczki (lub kobiety zatrudniane sezonowo) -8 do 16 koron na tydzień. W fabryce stosowano system płacy godzinowy i akordowy, praca trwała od 7 do $18, \mathrm{z} 15 \mathrm{~min}$. przerwą na śniadanie i godzinną na obiad. Osoby pracujące w nocy (od 21 do 6) w godzinach nadliczbowych dostawały $50 \%$ dodatek. Płace w fabryce były wyższe o ok. $30-40 \%$ niż w innych zakładach tego typu. Osobliwością był fakt, że wypłat dokonywał osobiście 
w każdą sobotę dyrektor Adam Piasecki, który w zależności od własnej oceny pracy przyznawał podwyżkę lub obniżał pensję danemu pracownikowi. ${ }^{2}$

Wojna 1914r. spowodowała spadek ilościowy i jakościowy produkcji, firma musiała zdecydować się na bardziej detaliczny charakter zbytu, dlatego w 1916r. Piasecki otworzył sklep fabryczny w Rynku Głównym 47 (linia A-B), w miejsce zlikwidowanego wcześniej sklepu przy ul. Floriańskiej 2 (sklep mieścił się w tym samym budynku Hotelu Drezdeńskiego).

Mimo okresowego spadku produkcji spowodowanego działaniami wojennymi firma rozwijała się nadal bardzo dobrze. Jednak Piasecki, widząc konieczność stawienia czoła nowym wyzwaniom w niepodległej Polsce i dokapitalizowania firmy w celu poczynienia nowych inwestycji w środki produkcji, zdecydował się na zakończenie okresu samodzielnego prowadzenia interesu. Wraz z 23 wspólnikami powołał więc spółkę pod nazwą: „A. Piasecki, fabryka czekolady i cukrów w Krakowie, spółka z ograniczoną odpowiedzialnością". Kapitał spółki był bardzo rozproszony (ryc.3), dlatego Adam Piasecki mając tylko $15 \%$ akcji, był jej największym udziałowcem.

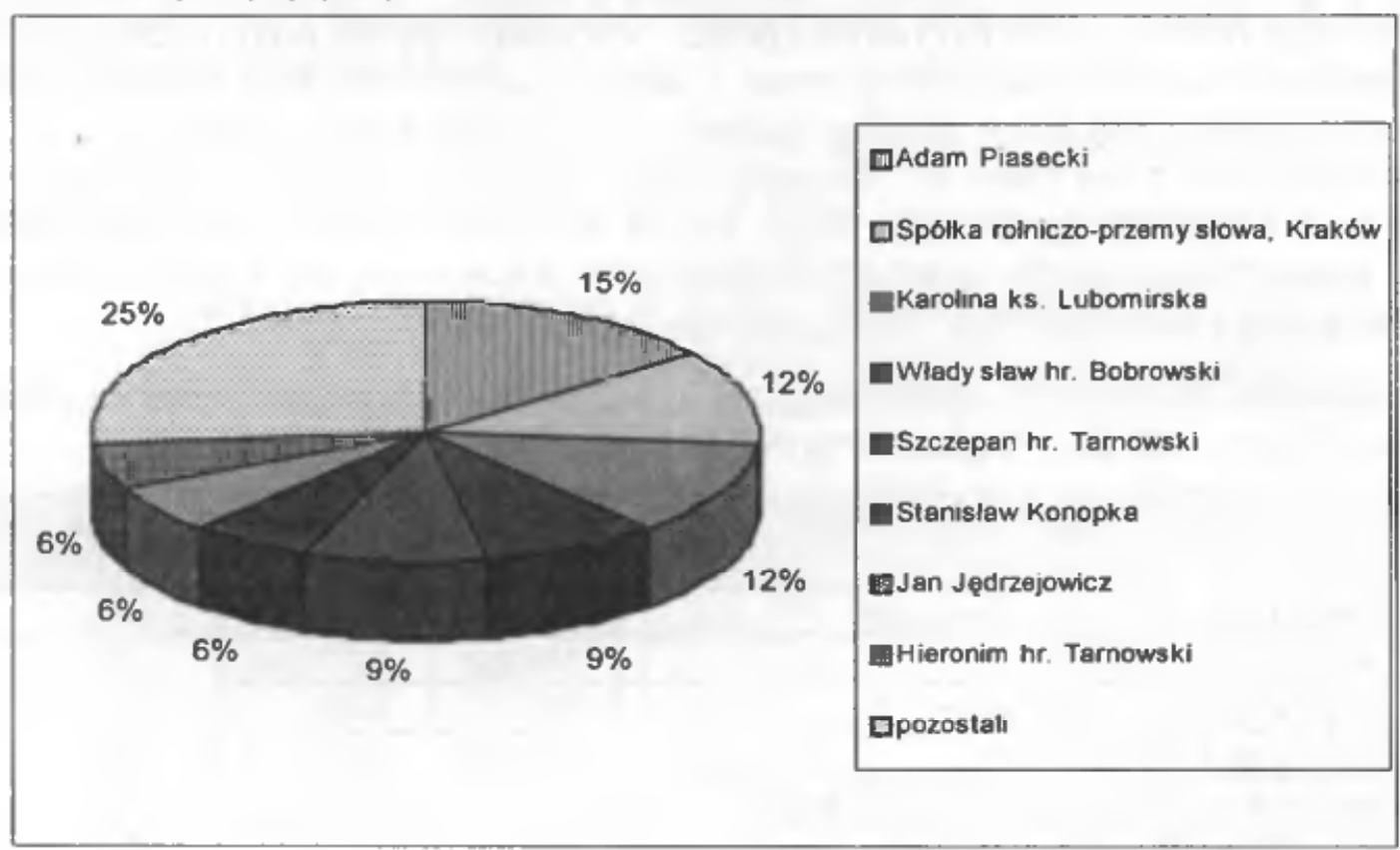

Ryc. 3. Struktura kapitału zakładowego sp. z o.o. "A.Piasecki, fabryka czekolady i cukrów w Krakowie" w dn. zał. Spółki.

\footnotetext{
${ }^{2}$ Należy dodać, że mimo cięzkich warunków pracy we wszystkich zakładach tego typu (ciasne lokale, wysoka temperatura, słaba wentylacja), Piasecki zasłynąl jako człowiek wyjątkowo życzliwy, dbający o swoich pracowników i uczniów, starając się zapewnić im w miarę możliwości jak najlepsze warunki pracy i placy. Dowodem tego wyjątkowego stosunku do swoich podwładnych był artykul, opublikowany w 1935 r. z okazji 50-lecia pracy zawodowej Piaseckiego i 25-lecia działalności fabryki czekolady w Ilustrowanym Kurierze Codziennym, w którym podkreśla się jego „ogromny dorobek moralny", „żelazną wolę, zapał do pracy, niespożytą wytrwałość, wielkie doświadczenie i to, co w świecie kupieckim nazywa się solidnością akuratnością i słownością". Autor stwierdza także, że „Piasecki był pierwszym, który małopolski przemysł cukierniczy postawił na wysokim poziomie technicznym i nadal mu rozmach przedsiębiorstwa w wielkim stylu, które dzięki swoim znakomitym wyrobom, zwycięsko rozprawiało się z potężną konkurencją firm wiedeńskich i innych" [IKC, 1935].
} 
Spółka ta nie funkcjonowała zbyt długo, gdyż właściciele od razu przystapili do realizacji zamiaru powołania spółki akcyjnej - najwyższej formy prawnej działalności przedsiębiorstw. 28.IX.1920r. został podpisany przez założycieli Statut spółki i tym samym rozpoczął się nowy etap działalności fabryki czekolady A. Piaseckiego. W myśl Statutu spółka powstała w celu: prowadzenia fabryki i wyrobu czekolady, cukrów, herbatników i w ogóle wszelkich produktów cukierniczych; budowy, nabywania i uruchomienia zakładów przemysłowych, przeznaczonych do osiągnięcia celów spółki; prowadzenia handlu produktami własnego wyrobu; prowadzenia wszelkich ubocznych i pomocniczych przemysłów, będących w związku z zasadniczym celem spółki.

Rada Zawiadowcza spółki składała się z 8 osób (prezesem został Szczepan hr. Tarnowski, viceprezesem dr Tadeusza Starzewski), dyrektorami zostali Adama Piasecki i Władysław hr. Bobrowski.

Kapitał spółki akcyjnej był jeszcze bardziej rozproszony w stosunku do rozkładu udziałów w spółce z ograniczoną odpowiedzialnością (tab.3). Należy jednak zauważyć, że większość akcji należała do kilku rodzin (przede wszystkim arystokratycznych), które na WZA reprezentowane były najczęściej przez 1 akcjonariusza, który miał stosowne pełnomocnictwa od reszty członków rodziny-akcjonariuszy. Adam Piasecki stracił status największego udziałowca (na rzecz hr. Szczepana Tarnowskiego), nie był też (podobnie jak w spółce z o.o.) jedynym dyrektorem. Nigdy jednak jego dyrektorstwo, jako założycielowi i twórcy potęgi firmy, nie było przez akcjonariuszy kwestionowane i aż do momentu aresztowania przez hitlerowców w 1944 r. pozostał jednym z dyrektorów firmy.

Tab. 3. Najwięksi udziałowcy spółki akcyjnej .„A.Piasecki, fabryka czekolady i cukrów w Krakowie" (pow. 200 akcji/8 głosów na WZ.A)

\begin{tabular}{|l|l|c|c|c|}
\hline Lp. & \multicolumn{1}{|c|}{ Imię i nazwisko (firma) } & $\begin{array}{c}\text { ilość } \\
\text { akcji }\end{array}$ & $\begin{array}{c}\text { \% kap. } \\
\text { akcyjnego }\end{array}$ & $\begin{array}{c}\text { ilość glosów } \\
\text { na WZA }\end{array}$ \\
\hline 1. & Tarnowski hr. Szczepan, Chorzelów & 1000 & 8,33 & 40 \\
\hline 2 & Piasecki Adam, Kraków & 740 & 6,17 & 29 \\
\hline 3. & Konopka Stanisław, Mogilany & 560 & 4,67 & 22 \\
\hline 4. & Kirchmayer Adam, Kraków & 500 & 4,17 & 20 \\
\hline 5. & Tarnowska hr. Wanda, Rudniki nad Sanem & 483 & 4,03 & 19 \\
\hline 6. & Bobrowski hr. Władysław, Kraków & 400 & 3,33 & 16 \\
\hline 7. & Potocki hr. Alfred, Lańcut & 400 & 3,33 & 56 \\
\hline 8. & Jędrzejowicz Jan, Staromieście p. Rzeszów & 370 & 3,08 & 14 \\
\hline 9. & Konarski hr. Stanisław, Kraków & 300 & 2,50 & 12 \\
\hline 10. & Spółka rolniczo-przemysłowa, Kraków & 299 & 2,49 & 11 \\
\hline 11. & Starzewski Dr Tadeusz, Kraków & 250 & 2,08 & 14 \\
\hline 12 & Zamoyska hr Zofia, Wysocko p. Bobrowka & 250 & 2,08 & 10 \\
\hline 13. & Bzowski Aleksander, Spass p. Stary Sambor & 200 & 1,67 & 8 \\
\hline 14. & Garczyński Zygmunt, Brzeźnica & 200 & 1,67 & 8 \\
\hline 15. & Lubomirska ks. Karolina, Bakończyce p. Przemyśl & 200 & 1,67 & 8 \\
\hline 16. & Lasocka hr. Marya, Kraków & 200 & 1,67 & 8 \\
\hline 17. & Miaczyński hr. Boleslaw, Korabniki p. Skawina & 200 & 1,67 & 8 \\
\hline 18. & Piątkowski A., Kraków & 200 & 1,67 & 8 \\
\hline 19. & Tarnowski hr. Adam, Warszawa & 200 & 1,67 & 8 \\
\hline 20. & pozostali & 5048 & 42,07 & x \\
\hline Razem & 1700 & 100,00 & x \\
\hline
\end{tabular}


Pierwszy rok działalności spółki akcyjnej (1920) mimo wielkich trudności w sprowadzaniu surowców i dostępności walut obcych (głównie z powodu wysokiej inflacji) był bardzo pomyślny. Ponieważ możliwości rozbudowy zakładu na terenie posesji przy ul. Szlak zostały wyczerpane, podjęto decyzję o zakupie parceli wraz z zabudowaniami niemal w centrum miasta przy ul. Wrocławskiej. Po adaptacji i rozbudowie stojących na niej budynków nowa fabryka, wyposażona w najnowocześniejsze maszyny, została uruchomiona w 1923r. Uruchomienie nowocześnie wyposażonej fabryki przy jednoczesnym wzroście zatrudnienia (tab. 4, ryc. 4) i wydajności przyniosło natychmiastowe efekty w postaci zwiększonych obrotów (tab. 5, ryc. 5) i zysków (tab.6, ryc.6), pomimo bardzo niekorzystnej sytuacji zewnętrznej. Na sytuację tę miała wpływ przede wszystkim konieczność działania w warunkach bardzo wysokiej inflacji oraz wyniszczającej Polskę wojnie celnej z Niemcami, która w pierwszym okresie powodowała ogromne trudności w imporcie surowców, głównie ziarna kakaowego, jednak w efekcie przyczyniła się do uniezależnienia polskich producentów (w tym fabryki A. Piaseckiego) od niemieckich pośredników w dostawach surowców do produkcji.

Tab. 4. Poziom i dynamika zatrudnienia w spółce akcyjnej "A.Piasecki, fabryka czekolady i cukrów w Krakowie" w latach 1920-1946.

\begin{tabular}{|c|c|c|c|}
\hline \multirow{2}{*}{ Rok } & \multirow{2}{*}{ Zatrudnienie } & \multicolumn{2}{|c|}{ Dynamika (\%) } \\
\cline { 3 - 4 } & & $1920 \mathrm{r} \cdot=100$ & rok poprzed.=100 \\
\hline 1920 & 100 & 100 & - \\
\hline 1921 & 135 & 135 & 135 \\
\hline 1927 & 423 & 423 & 313 \\
\hline 1935 & 248 & 248 & 59 \\
\hline 1936 & 275 & 275 & 111 \\
\hline 1938 & 281 & 281 & 102 \\
\hline 1946 & 346 & 346 & 123 \\
\hline
\end{tabular}

II połowa lat 20. upłynęła pod znakiem hossy w gospodarce. Wraz ze wzrostem gospodarczym rosły dochody ludności i tym samym popyt na wyroby cukiernicze, szczególnie w dużych miastach. W związku z tym w latach 1925-26 dokonano dalszej rozbudowy fabryki przy ul. Wrocławskiej. Dzięki temu w 1927 roku zatrudnienie osiągnęło najwyższy poziom $-423^{3}$ osoby. Akcje spółki, notowane na krakowskiej giełdzie osiągały wysoki kurs, np. w 1927 roku systematycznie rosły z 13,20 zł do 16,50 zł, tj. o $25 \%$ w ciągu roku [Spólki akcyjne w Polsce, 1928].

\footnotetext{
${ }^{3}$ wg innych źródel - 330 osób [Polski słownik biograficzny, 1980].
} 


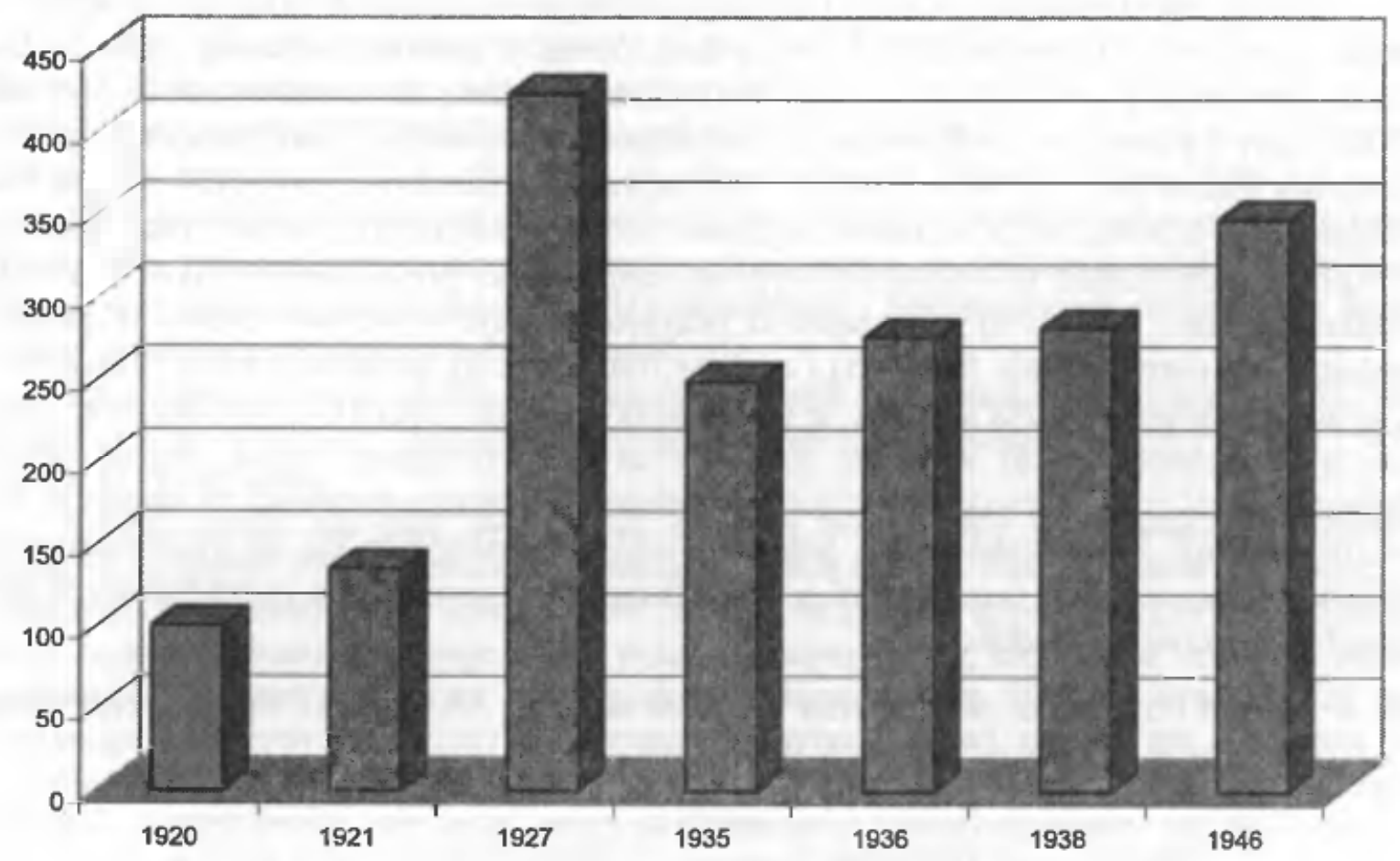

Ryc. 4. Zmiany poziomu zatrudnienia w spółce akcyjnej "A.Piasecki, fabryka czekolady i cukrów w Krakowie" w latach 1920-1946.

Tab. 5. Poziom i dynamika przychodów ze sprzedaźy wyrobów spólki akcyjnej "A.Piasecki, fabryka czekolady i cukrow" w latach 1929-1942.

\begin{tabular}{|c|c|c|c|}
\hline \multirow{2}{*}{ Rok } & \multirow{2}{*}{$\begin{array}{c}\text { Przychody ze } \\
\text { sprzedaży } \\
\text { (tys. zl) }\end{array}$} & \multicolumn{2}{|c|}{ Dynamika (\%) } \\
\cline { 3 - 4 } & 10110,5 & 100,0 & rok poprzed.=100 \\
\hline 1929 & 9680,9 & 95,8 & - \\
\hline 1930 & 7376,9 & 73,0 & 95,8 \\
\hline 1931 & 5733,6 & 56,7 & 76,2 \\
\hline 1932 & 5504,2 & 54,4 & 97,7 \\
\hline 1933 & 5235,3 & 51,8 & 96,0 \\
\hline 1934 & 4474,1 & 44,3 & 85,1 \\
\hline 1935 & 4348,3 & 43,0 & 97,2 \\
\hline 1936 & 4559,5 & 45,1 & 104,9 \\
\hline 1937 & 4705,3 & 46,5 & 103,2 \\
\hline 1938 & 4006,2 & 39,6 & 85,1 \\
\hline 1939 & 5757,2 & 56,9 & 143,7 \\
\hline 1941 & 4833,7 & 47,8 & 84,0 \\
\hline 1942 & & & \\
\hline
\end{tabular}


Pod koniec lat 20. firma Piaseckiego rozpoczęła ostrą walkę konkurencyjna ze znaną warszawską firmą Emila Wedla, która zrywając dotychczasową umowę, uruchomiła sklep w Krakowie. W odpowiedzi na to posunięcie również Piasecki założył sklep w Warszawie.

Korzystne warunki rozwoju firmy ulegały stopniowemu pogarszaniu się wraz z pojawiającymi się oznakami wielkiego kryzysu gospodarczego. Rok 1930 był jeszcze korzystnym w rozwoju produkcji spółki. Mimo stagnacji na rynku, spowodowanej zubożeniem społeczeństwa, obroty spadły w stosunku do roku poprzedniego tylko o $4 \%$, natomiast zyski utrzymały się na dotychczasowym poziomie i możliwa była wypłata dywidendy.

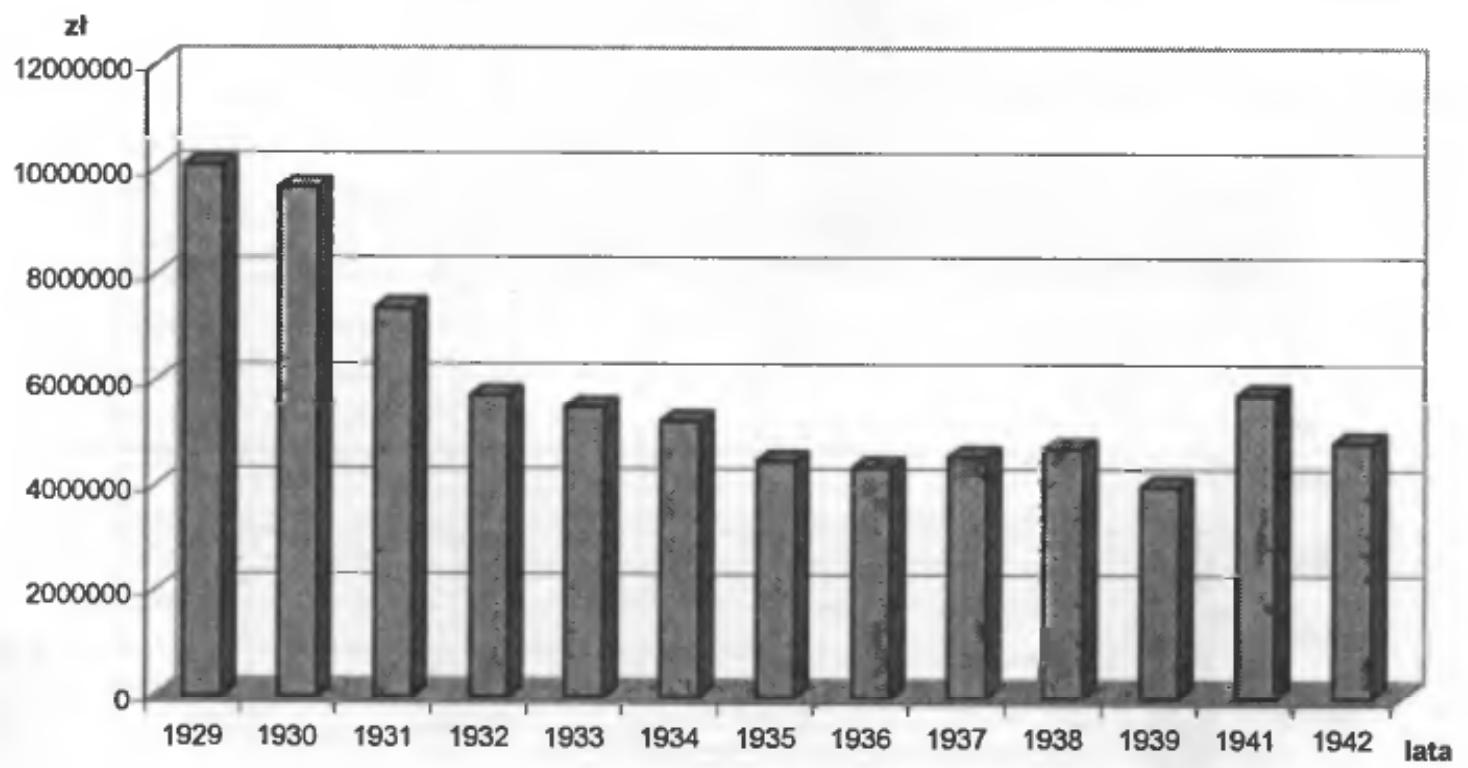

Ryc. 5. Przychody ze sprzedaży wyrobów spółki akcyjnej "A.Piasecki, fabryka czekolady i cukrów" w latach 1929-1942.

Kolejne lata wielkiego kryzysu przyniosły dalszy spadek produkcji. W głównym stopniu spowodowane to było: załamaniem się gospodarki społecznej, „stanięciem handlu i produkcji" w całym kraju; zwiększaniu się rozmiarów bezrobocia; zubożeniem rolników i klasy urzędniczej oraz drobnomieszczaństwa (końcowych, detalicznych klientów firmy); niesumiennością odbiorców (zaleganiem z płatnościami); bardzo uciążliwymi, wysokimi podatkami; brakiem kapitału obrotowego w odpowiedniej wysokości. 
Tab. 6. Kształtowanie się zysków (strat) spółki akcyjnej "A.Piasecki, fabryka czekolady i cukrów" w latach 1929-1942.

\begin{tabular}{|c|c|}
\hline Rok & $\begin{array}{c}\text { Zyski - straty } \\
\text { (tys. zi) }\end{array}$ \\
\hline 1924 & 520,4 \\
\hline 1927 & 140,6 \\
\hline 1930 & 162,2 \\
\hline 1931 & 93,7 \\
\hline 1932 & $-160,0$ \\
\hline 1933 & $-25,0$ \\
\hline 1934 & 2,3 \\
\hline 1935 & $-120,0$ \\
\hline 1936 & $-120,7$ \\
\hline 1937 & 14,4 \\
\hline 1939 & 82,9 \\
\hline 1942 & 368,2 \\
\hline
\end{tabular}

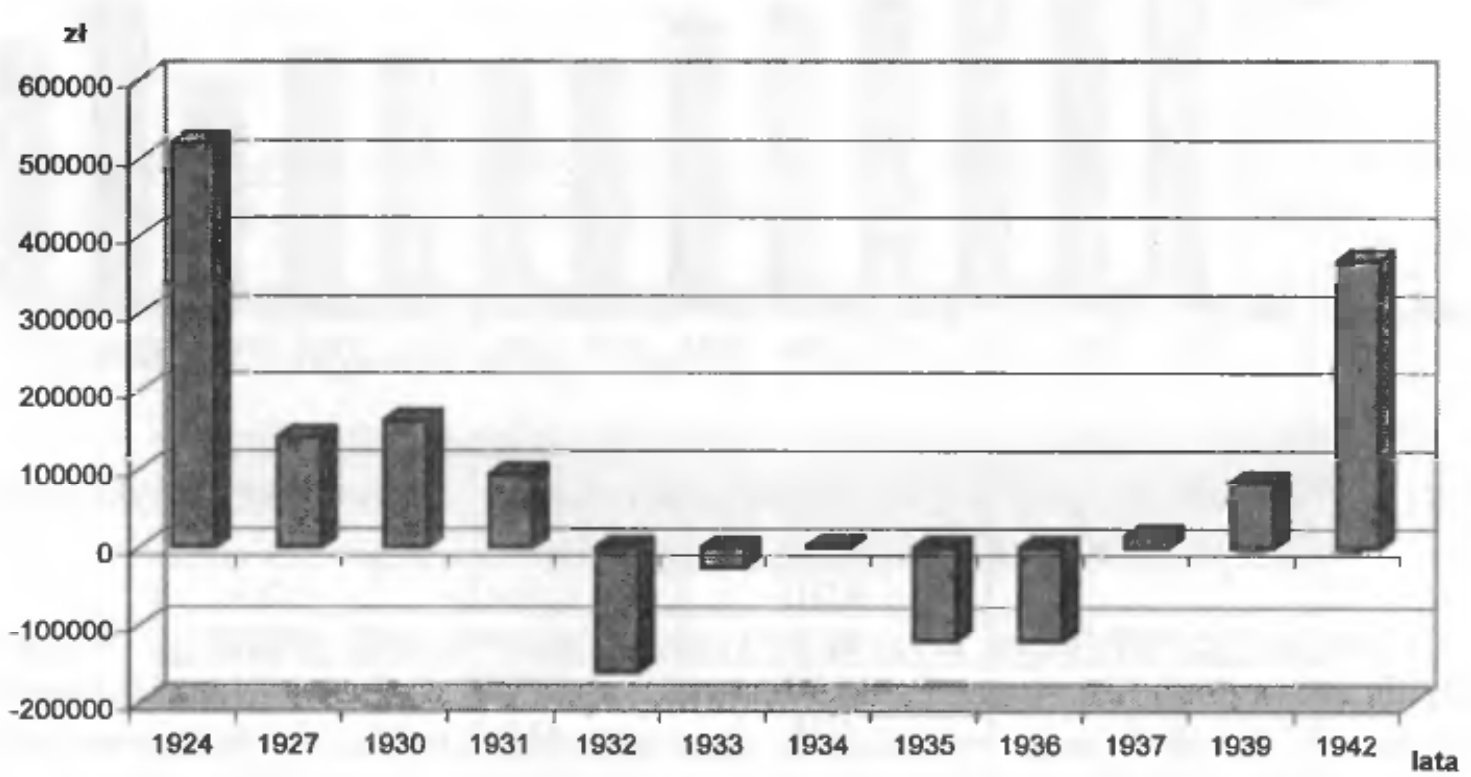

Ryc. 6. Kształtowanie się zysków (strat) spółki akcyjnej "A.Piasecki, fabryka czekolady i cukrów" w latach 1924-1942

W celu przeciwdziałania niekorzystnym tendencjom ograniczenie produkcji zarząd podjął działania mające na celu obniżkę kosztów pracy poprzez obniżenie poborów - średnio o $10-15 \%$ i redukcję zatrudnienia o $10-15$ osób oraz celowe przesunięcie asortymentu produkcji w kierunku tańszych wyrobów, przy zachowaniu nadal wysokiej jakości surowców w produkcji. Na pierwszym miejscu stawiane było bowiem dobre imię firmy, dlatego nie zdecydowano się na obniżenie gatunku produkowanych wyrobów, jak czyniły to inne firmy. 
Najgorsza sytuacja nastąpiła w 1935r., w którym produkcja (tab. 7, ryc. 7) i sprzedaż spadła o ponad $14 \%$ (w porównaniu z rokiem poprzednim). Na sytuację taką największy wpływ miały działania antykryzysowe rządu. W odniesieniu do fabryki największe trudności spowodowało ustanowienie w kwietniu 1935r. kontyngentów na import surowców (m.in. ziarna, masła kakaowego, orzechów). Spowodowało to redukcję zaopatrzenia z importu o $50 \%$ oraz bardzo duże opóźnienia w dostawach (nawet o 1-2 miesiące), z powodu czekania na załatwienie formalności importowych. W celu utrzymania produkcji na normalnym poziomie i sprostaniu zamówieniom, spółka musiała zaopatrywać się w brakujące surowce u hurtowników, którzy wykorzystując sytuację podwyższali ceny na rynku wewnętrznym. Jednocześnie dała się odczuć konkurencja tańszych fabryk ,anonimowych" oraz wojna cenowa pomiędzy producentami czekolady, prowadząca do spadku cen zbytu, mimo wzrostu cen surowc 6 w. W tej sytuacji konieczna była w 1935 r. dalsza redukcja zatrudnienia do 248 osób.

Tab. 7. Poziom i dynamika produkcji rocznej wyrobów spółki akcyjnej "A.Piasecki, fabryka czekolady i cukrów" w latach 1933-1942.

\begin{tabular}{|c|c|c|c|}
\hline \multirow{2}{*}{ Rok } & \multirow{2}{*}{$\begin{array}{c}\text { Produkcja roczna } \\
(\mathrm{t})\end{array}$} & \multicolumn{2}{|c|}{ Dynamika (\%) } \\
\cline { 3 - 4 } & 1225,5 & $1933 \mathrm{r}=100$ & rok poprzed. $=100$ \\
\hline 1933 & 1112,6 & 90,8 & - \\
\hline 1934 & 954,8 & 77,9 & 90,8 \\
\hline 1935 & 921,4 & 75,2 & 85,8 \\
\hline 1936 & 942,0 & 76,9 & 96,5 \\
\hline 1937 & 993,2 & 81,0 & 102,2 \\
\hline 1938 & 751,6 & 61,3 & 105,4 \\
\hline 1939 & 452,8 & 36,9 & 75,7 \\
\hline 1940 & 538,0 & 43,9 & 60,2 \\
\hline 1941 & 481,9 & 39,3 & 118,8 \\
\hline 1942 & & & 89,6 \\
\hline
\end{tabular}

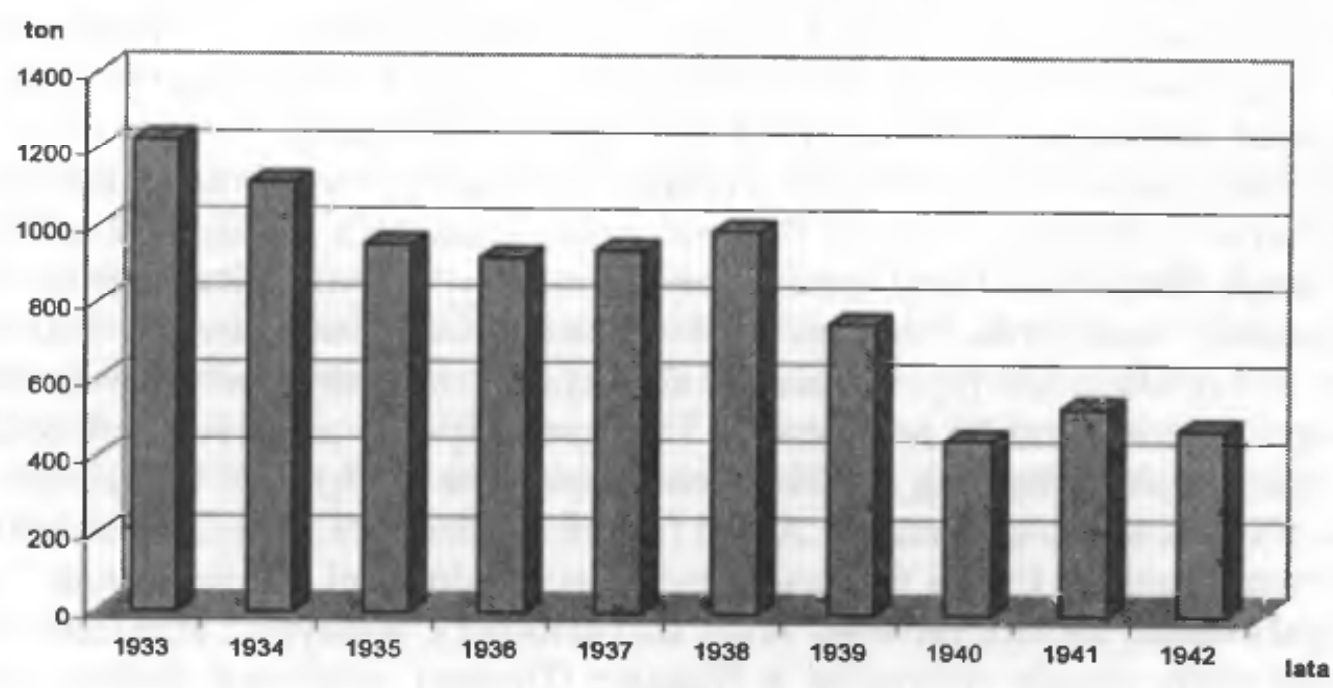

Ryc. 7. Produkcja roczna wyrobów spółki akcyjnej "A.Piasecki, fabryka czekolady i cukrów" w latach 1933-1942. 
Sytuacja przedsiębiorstwa w latach $1930-35$ była w dużej mierze odzwierciedleniem ogólnych tendencji gospodarczych w Polsce wynikających z wielkiego kryzysu gospodarczego. Pogarszająca się sytuacja na rynku była w znacznym stopniu wynikiem działań konkurencyjnych, przejawiających się m.in. w wojnach cenowych. W efekcie w latach 1928-1935 nastappil spadek cen hurtowych żywności o 51\%. W celu utrzymania cen na odpowiednim poziomie powstawały liczne porozumienia kartelowe, ale spowodowało to znaczne ograniczenie popytu. Poza tym, mimo licznych rozmów zarządów fabryk, nie udało się przedsiębiorstwom cukierniczym utworzyć skutecznego kartelu utrzymującego ceny na poziomie gwarantującym opłacalność produkcji (musieli natomiast płacić wysokie ceny kartelom dostarczającym surowce). [Kaliński, Landau, 1998]. Liczne próby ustalenia cen minimalnych zaowocowały tylko porozumieniem 4 fabryk (A.Piaseckiego, Sucharda, Goplany i Fuchsa). Nie przystąpienie innych dużych producentów czekolady do takich porozumień (m.in. E.Wedla, Branki, Plutosa), przyczyniało się do dalszej obniżki cen zbytu i tym samym spadku rentowności produkcji. W efekcie trudna sytuacja gospodarcza doprowadziła w Polsce do upadku w latach kryzysu ok. 8 tys. dużych przedsiębiorstw produkcyjnych, mimo działań rządu zachęcających do inwestowania i tworzenia nowych miejsc pracy. W tej sytuacji funkcjonowanie fabryki czekolady A.Piasecki można uznać za sukces.

Zasięg rynku zbytu fabryki A.Piaseckiego obejmował (na podstawie korespondencji handlowej z 1934 i 1935 r.) cały obszar Polski, w tym duże miasta: Kraków, Warszawę, Poznań, Lódź, Lublin, Wilno, Lwów oraz region Śląska, Polskę północną (m.in. Gdynia, Grudziądz, Toruń, Włocławek, Suwałki), centralną (oprócz wymienionych: Radom, Piotrków Trybunalski, Częstochowa, Skarżysko), południową (m.in. Myślenice, Zakopane, Sucha, Krynica) oraz wschodnią, łącznie z tzw. kresami (poza wymienionymi m.in. Grodno, Lida, Brześć, Rzeszów, Przemyśl, Luck, Równe). Wyroby były również eksportowane, przede wszystkim do Wolnego Miasta Gdańska, na Litwę oraz do ZSRR ${ }^{4}$. W sumie towar wysyłano do stu kilkudziesięciu odbiorców. Należy jednak zwrócić uwagę, że zasięg ten mógł być jeszcze szerszy, gdyż w wielu dużych miastach fabryka miała niezależnych ,jeneralnych reprezentantów" i za ich pośrednictwem towar był sprzedawany dalej (przedstawicielstwa były m.in. w Chorzowie, Lwowie, Lodzi, Poznaniu, Tarnowie i Warszawie). Ponadto w kwestionariuszu dla Izby Przemysłowo-Handlowej firma podała, że wyeksportowała karmelki do Stanów Zjednoczonych i czekoladę do Mandżurii.

Natomiast surowce i materiały do produkcji pochodziły przede wszystkim z importu: ziarno kakaowe z Holandii, Francji i Brazylii, masło kakaowe z Holandii, orzechy i migdały z Francji, Hiszpanii i Turcji, koncentraty różnego typu i aromaty z Niemiec, wanilię z Francji, sezam mandżurski z Japonii. Niektóre surowce kupowane były w Polsce u pośredników lub producentów (np. w maczek cukrowy biały zaopatrywano się w Królewskiej Hucie). Opakowanie wyrobów pochodziły z Tomaszowa (papier przezroczysty), ze Szwecji (lignina tłoczona do pomadek), Bielska (wata papierowa tj. lignina), Hamburga i Pragi (folie aluminiowe, staniole), Leeds w Anglii (pudełka kolorowe), Dziedzic (kartony), Krakowa (kartony, papier). Usługi drukarskie były zlecane drukarni „Głosu Narodu” w Krakowie (opakowania, papiery firmowe, druki akcydensowe). Maszyny i urządzenia do produkcji pochodziły przede wszystkim z Niemiec (Drezno), natomiast drobne narzędzia

\footnotetext{
${ }^{4}$ Mimo braku wiarygodnych dokumentów možna przypuszczać, że wyroby były także eksportowane przez pośredników do Niemiec (mimo skomplikowanej sytuacji politycznej) oraz Czechosłowacji.
} 
i galanteria metalowa $\mathrm{z}$ hut i zakładów na Śląsku. W pozostałe surowce, materiały i urządzenia do produkcji zaopatrywano się u pośredników, których siedziby mieściły się przede wszystkim w Krakowie i Warszawie.

W 1937 r. firma przełamała ostatecznie trudności, zwiększono produkcję i zatrudnienia, odnotowano znowu zyski. Kolejny rok przyniósł również wzrost produkcji, przychodów ze sprzedaży i zatrudnienia. Spółka była na najlepszej drodze do odzyskania świetności i wysokich zysków z II połowy lat 20., jednak skomplikowana sytuacja polityczna i wybuch II wojny światowej przekreśliły te prognozy. W raporcie rocznym zarządu 1939 rok został określony jako stracony w 30 procentach (przerwy w produkcji spowodowane usuwaniem bomb i likwidacją zniszczeń, zupełny spadek obrotów w IV kwartale z niezależnymi odbiorcami, niezłą sprzedaż miały tylko własne sklepy). Mimo kompletnego załamania produkcji w drugim roku wojny A.Piasecki zdecydował się na przeprowadzenie przebudowy fabryki. W 1941r. pod naciskiem okupanta, do władz spółki wszedł Niemiec, jako 4 członek zarządu. Był to wtedy jedyny sposób na uniknięcie całkowitej konfiskaty fabryki przez Niemców. Rok ten nazwany został przez zarząd „gospodarką planową”, gdyż okupant regulował całkowicie zbyt towarów, ustanawiał ceny urzędowe na produkowany asortyment, przyznawał kontyngenty zaopatrzeniowe itp. Przyniosło to jednak względną stabilizację i w konsekwencji wzrost sprzedaży w 1941r. w porównaniu z 1940r., chociaż nadal wskaźnik ten był niższy o ok. $50 \% \mathrm{w}$ porównaniu $\mathrm{z}$ latami przedwojennymi. W 1942r. produkcja ponownie spadła, zanotowano zysk, ale przy ocenie działalności spółki w tym czasie należy wziąć pod uwagę, że wszelkie istotne decyzje (w tym źródła zaopatrzenia, ceny, wielkość i kierunki zbytu towarów) regulowane były przez władze Generalnej Guberni, a ich wykonywanie ściśle kontrolowane przez przedstawiciela okupanta w zarządzie spółki.

W latach 1943-1944 produkcja ograniczała się w zasadzie tylko do karmelków i suchego pieczywa cukierniczego na potrzeby niemieckie. Pod koniec 1944r. przerwano produkcję a budynki fabryczne przejął Wermacht. Największym ciosem dla firmy było aresztowanie założyciela i dyrektora spółki Adama Piaseckiego w dn. grudniu 1944 roku za przydzielenie robotnikom deputatu w postaci słodyczy.

Niemal natychmiast po wycofaniu się Niemców z Krakowa, jeszcze w styczniu 1945r. podjęto w fabryce A. Piaseckiego produkcję. Zatrudnienie w r. 1946 wynosiło już 344 osoby przy miesięcznej produkcji ok. 15 tys. kg miesięcznie. W tym samym roku fabryka została upaństwowiona i weszła pod zarząd Zjednoczenia Przemysłu Cukierniczego, a następnie w skład ZPC „Wawel”.

Już w rok po założeniu pierwszej w Krakowie fabryki czekolady przez A.Piaseckiego powstała następna: „Pierwsza Galicyjska Fabryka Warszawskich Cukrów i Marmolady A.Sobolewski i Spółka”. Należała do czterech wspólników (ryc.8), z których 3 miało aż 98\% udziałów, ale inicjatorem założenia spółki i fabryki był Witold Sobolewski, który po przybyciu z Warszawy do Krakowa chciał uruchomić fabrykę opartą na produkcji wg receptur warszawskich i rosyjskich. 


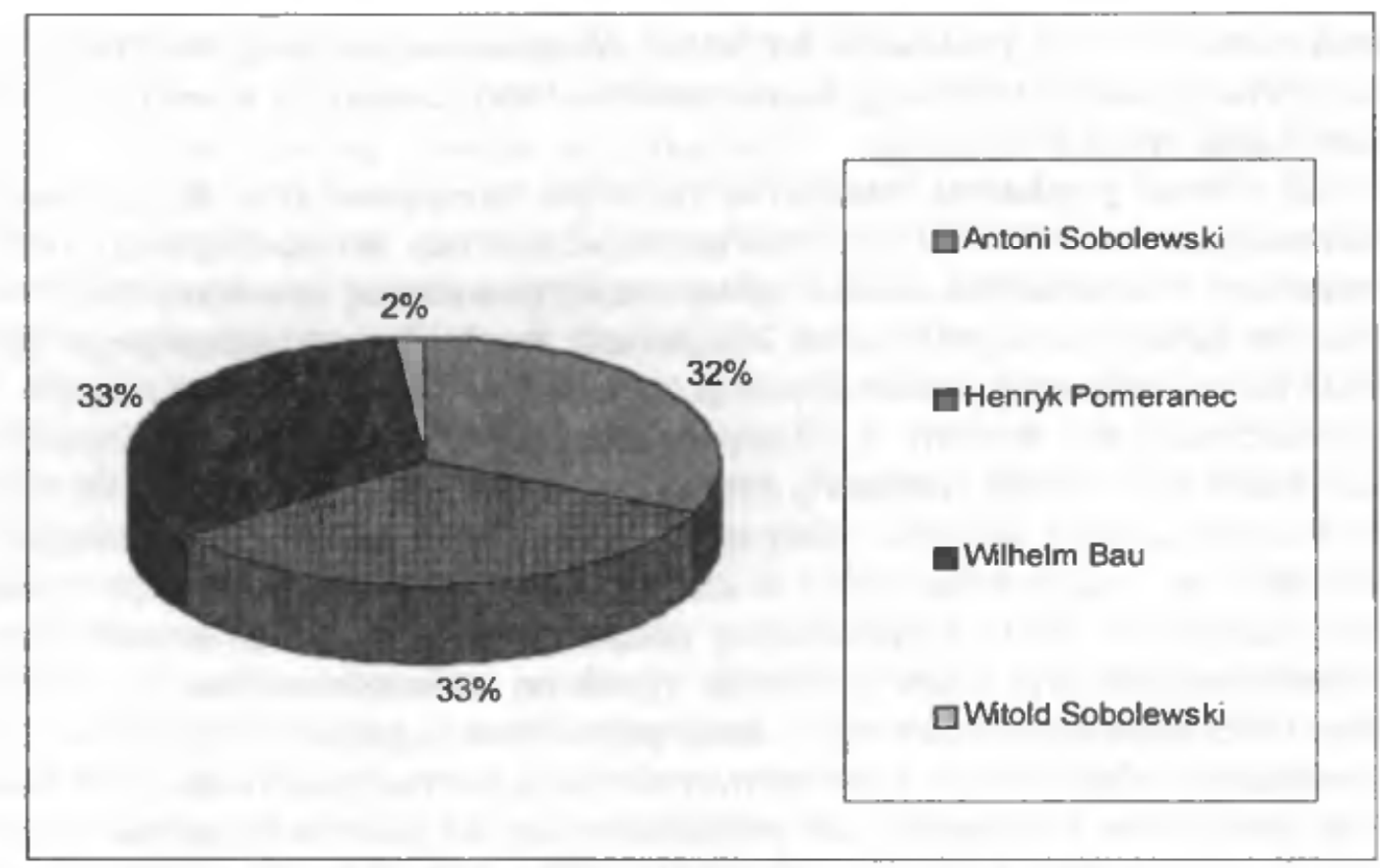

Ryc. 8. Kapitał zakładowy sp. z o.o. "Pierwszej Galicyjskiej Fabryki Warszawskich Cukrów i Marmolady A.Sobolewski i S-ka" w dn. zał. spółki

Fabryka mieściła się w Podgórzu, przy ul. Kącik 10. Warunki pracy były bardzo prymitywne, niemal wszystkie prace były wykonywane ręcznie, dopiero w 1912r. sprowadzono kilka podstawowych maszyn o sile zaledwie $12 \mathrm{KM}$. Produkowano warszawskie karmelki twarde i nadziewane, cukry petersburskie, irysy śmietankowe, szyjki rakowe, koguciki, cukierki lira. Specjalnością fabryki były karmelki „Napoleon”, marmoladki owocowe, smażone w cukrze owoce, orzechy i migdały. W późniejszym czasie produkowano także pralinki i czekoladki. W początkowym okresie wytwórnia zatrudniała 21 osób, w tym 3 majstrów, dzienna produkcja wynosiła ok. $350 \mathrm{~kg}$. W miarę przybywania klientów i nowych zamówień produkcja wzrosła do $600-800 \mathrm{~kg}$ dziennie i co za tym idzie, konieczne było zwiększenie zatrudnienia. W 1914 roku nastappiły istotne zmiany wśród udziałowców: Sobolewscy wystąpili ze spółki (tym samym musiano wykreślić ich nazwisko z nazwy), ostatecznie uległa ona likwidacji wskutek kryzysu w latach 1929-34.

Witold Sobolewski zawiązał tymczasem w 1914 r. nową spółkę pod nazwą: „Kryształ - Polska Fabryka Cukrów i Czekolady wyrabianych systemem Witolda Sobolewskiego, sp. z o.o." Siedziba spółki mieściła się przy ul. Salinamej 25. W kolejnych latach zmienili się wspólnicy, a fabryka od 1923 roku przyjęła nazwę „Parowa Fabryka Cukrów i Czekolady - Kryształ Sp. z o.o." Początkowo zatrudnienie wynosiło 25 osób (tab. 8, ryc.9). W 1915r. pomieszczenia fabryczne przebudowano, zwiększono zatrudnienie o $28 \%$, tj. do 32 osób (byli to przede wszystkim pracownicy Sobolewskiego z poprzedniej spółki). Produkcja obejmowała głównie karmelki i marmoladki oraz pieczywo cukiernicze oblewane czekoladą i wynosiła 350-400 kg dziennie. W 1922 r. zatrudniała już ok. 100 osób, jednak poziom zatrudnienia obniżył się na początku lat 30 . Fabryka posiadała sklep przy Rynku Głównym nr 7. W czasie II wojny światowej fabryka została przejęta przez Niemców, a po wojnie jej majątek został przekazany ZPC „Wawel”. 
Tab. 8. Poziom i dynamika zatrudnienia w „Parowej Fabryce Cukrów i Czekolady Kryształ, sp. z o.o." w latach 1914-1936.

\begin{tabular}{|c|c|c|c|}
\hline \multirow{2}{*}{ Rok } & \multirow{2}{*}{ Zatrudnienie } & \multicolumn{2}{|c|}{ Dynamika (\%) } \\
\cline { 3 - 4 } & & $1914 \mathrm{r}=100$ & rok poprzed $=100$ \\
\hline 1914 & 25 & 100 & - \\
\hline 1915 & 32 & 128 & 128 \\
\hline 1922 & 100 & 400 & 313 \\
\hline 1932 & 64 & 256 & 64 \\
\hline 1934 & 77 & 308 & 120 \\
\hline 1936 & 110 & 440 & 143 \\
\hline
\end{tabular}

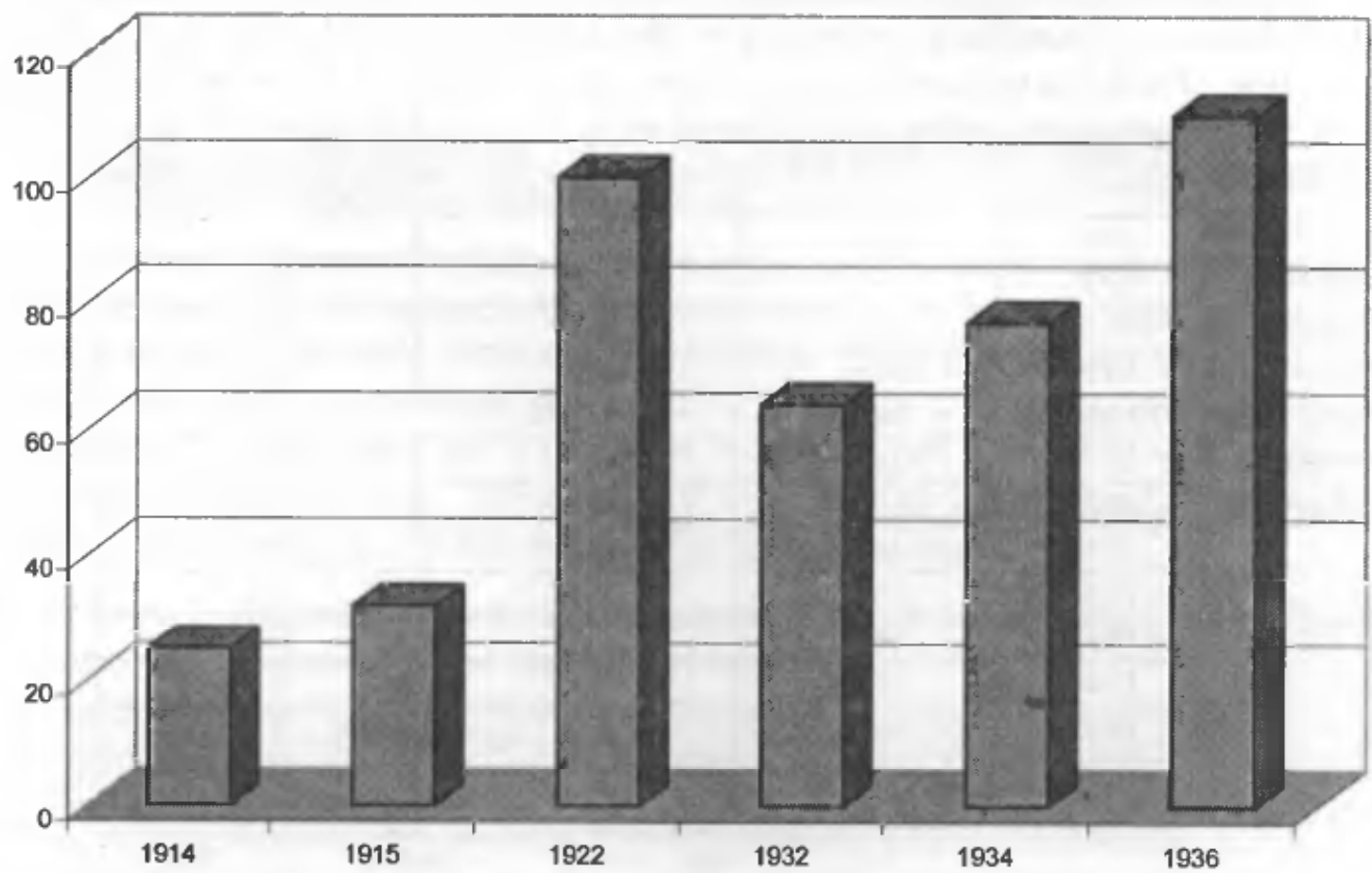

Ryc. 9. Zmiany poziomu zatrudnienia w „Parowej Fabryce Cukrów i Czekolady - Kryształ, sp. z o.o." w latach 1914-1936.

Kolejnym fabryką cukiernicza, założoną w 1922r. była spółka z ograniczoną poręką pod nazwą: „Pischinger i Spółka”. Spółce nie wiodło się najlepiej, dlatego w 1929r. zlicytowano majątek, na bazie którego nowi właściciele założyli spółkę pod nazwą „Fabryka Wyrobów Czekoladowych J.Pischinger-Triumf i S-ka”. Fabryka miała siedzibę w Podgó- 
rzu, przy ul. Kącik 22 i zajęła się produkcją tanich wyrobów niskiej jakości. Dysponowała jedynie jedną maszyną parową o mocy $60 \mathrm{KM}$. W pierwszym roku działalności zatrudniała 105 osób, w kolejnych latach zatrudnienie wzrastało osiągając poziom w 1934r. - 200, a w 1938r. 314 osób. W czasie okupacji firma została przejęta przez Niemców (formalnie wyrejestrowana i ponownie zarejestrowana jako niemiecka, dlatego cała dokumentacja została przez okupanta wywieziona w czasie wycofywania się z Polski).

Korzystne warunki działalności i wysokie prognozy zysków przyciągnęły do Polski także zagraniczny kapitał szwajcarski. W 1925 r. została założona przez Harrego Laxa i Maxa Hoffmana „Hofla” - spółka z ograniczoną odpowiedzialnością z siedzibą w Krakowie, przy ul. Masarskiej 6. Na mocy umowy ze szwajcarską spółką akcyjną Suchard firma zmieniła nazwę na „Polska Fabryka Czekolady Suchard, spółka z o.o.”, zaczęła produkować wyroby licencyjne, a w przyszłości miała zostać przekształcona w spółkę akcyjną. Szybko osiągnięto dużą moc wytwórczą, produkując w 1927 r. dziennie ok. $3000 \mathrm{~kg}$ czekolady twardej, $500 \mathrm{~kg}$ czekoladek, pralinek i pomadek. W produkcji wykorzystywano 25 motorów o sile $300 \mathrm{KM}$. Wzrastał także poziom zatrudnienia - z 78 osób w 1926 r. do 227 osób na przełomie 1927/1928 r., tj. blisko trzykrotnie (tab. 9, ryc.10).

Tab. 9. Poziom i dynamika zatrudnienia w „Polskiej fabryce czekolady Suchard sp. z o.o.” oraz „Polsko-szwajcarskiej fabryce czekolady Suchard S.A.” w latach 1926-1938.

\begin{tabular}{|c|c|c|c|}
\hline \multirow{2}{*}{ Rok } & \multirow{2}{*}{ Zatrudnienie } & \multicolumn{2}{|c|}{ Dynamika (\%) } \\
\cline { 3 - 4 } & & $1926 \mathrm{r}=100$ & rok poprzed. $=100$ \\
\hline 1926 & 78 & 100 & - \\
\hline 1927 & 152 & 195 & 195 \\
\hline 1928 & 227 & 291 & 149 \\
\hline 1929 & 351 & 450 & 155 \\
\hline 1930 & 340 & 436 & 97 \\
\hline 1931 & 340 & 436 & 100 \\
\hline 1932 & 450 & 577 & 132 \\
\hline 1933 & 440 & 564 & 98 \\
\hline 1934 & 554 & 710 & 126 \\
\hline 1935 & 562 & 721 & 101 \\
\hline 1936 & 555 & 712 & 99 \\
\hline 1937 & 462 & 592 & 83 \\
\hline 1938 & 466 & 597 & 101 \\
\hline
\end{tabular}

Zgodnie z umową w 1928 r. zawiązano spółkę akcyjną „Polsko-szwajcarska fabryka czekolady Suchard S.A.”. Połowę udziałów w nowej spółce miał koncern szwajcarski Suchard S.A., 30\% rodzina Lax-ów (w zamian za wniesiony majątek produkcyjny), pozostałe $20 \%$ inwestor angielski. 


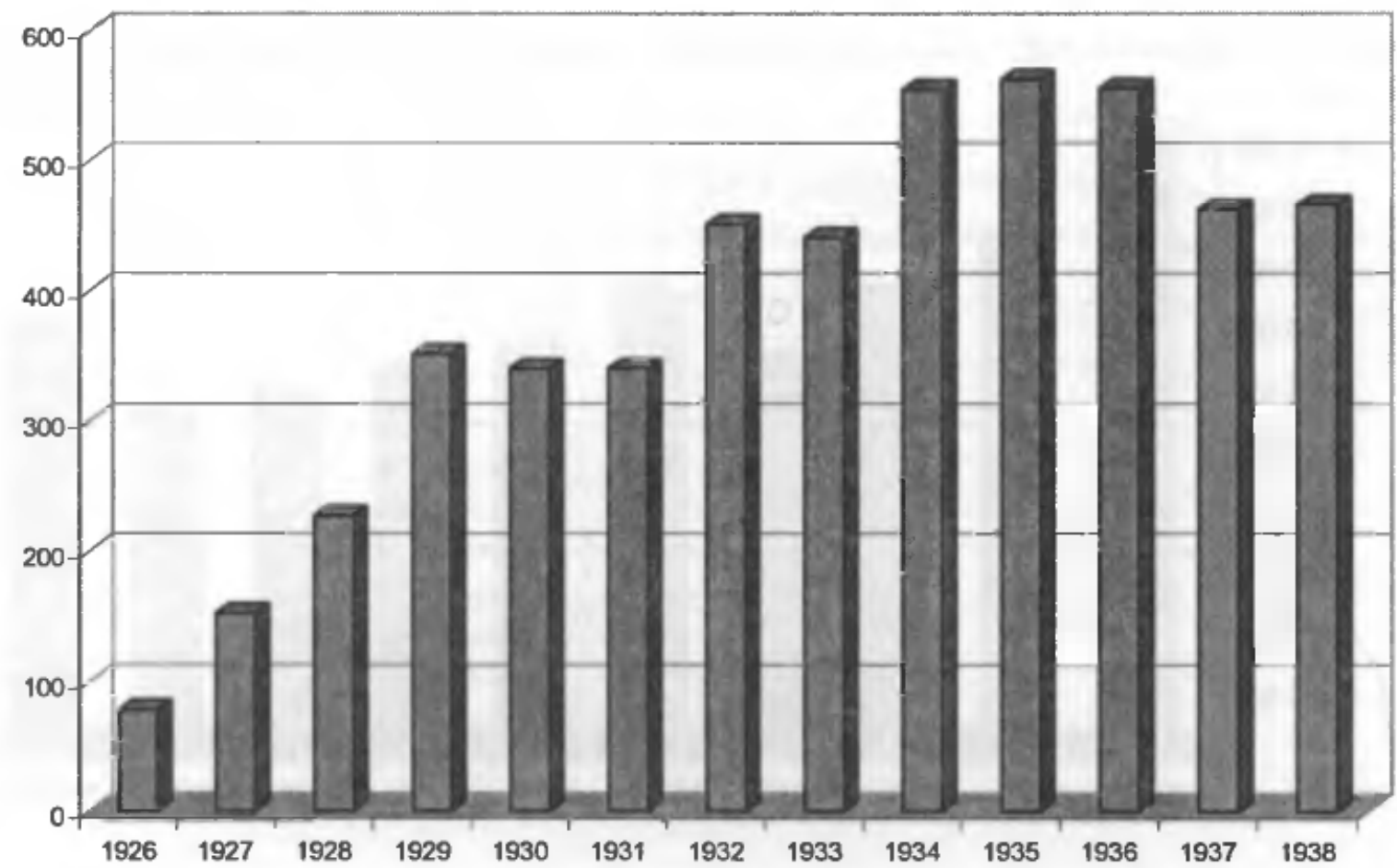

Ryc.10. Zmiany poziomu zatrudnienia w „Polskiej fabryce czekolady Suchard sp. z o.o.” oraz „Polsko-szwajcarskiej fabryce czekolady Suchard S.A.” w latach 1926-1938.

Dzięki dużemu kapitałowi zakładowemu, bardzo nowoczesnemu parkowi maszynowemu (głównie pochodzenia szwajcarskiego) oraz doskonałym szwajcarskim recepturom (m.in. znanej do dziś czekolady „Milka”) i technologii produkcji, spółka błyskawicznie zajęła pozycję jednego $\mathrm{z}$ największych producentów tej branży w kraju. W drugiej połowie lat 20. w Polsce funkcjonowało ok. 110 fabryk cukierniczych (w tym 8 w Krakowie), o łącznych obrotach ok. 70 mln zł i zatrudnieniu 9 tys. osób. Udział "Sucharda" wg wielkości sprzedaży na polskim rynku można więc szacować na ok. $10 \%$.

Tab. 10. Poziom i dynamika przychodów z działalności „Polsko-szwajcarskiej fabryki czekolady Suchard S.A." w latach 1929-1938.

\begin{tabular}{|c|c|c|c|}
\hline \multirow[t]{2}{*}{ Rok } & \multirow{2}{*}{$\begin{array}{l}\text { Przychody z } \\
\text { działalności } \\
\text { (tys. zl) }\end{array}$} & \multicolumn{2}{|c|}{ Dynamika (\%) } \\
\hline & & $1929 \mathrm{r} .=100$ & rok poprzed $=100$ \\
\hline 1929 & 9964,0 & 100 & - \\
\hline 1930 & 8270,4 & 83 & 83 \\
\hline 1931 & 7441,8 & 75 & 90 \\
\hline 1932 & 6343,6 & 64 & 85 \\
\hline 1933 & 7458,5 & 75 & 118 \\
\hline 1934 & 6618,8 & 66 & 89 \\
\hline 1935 & 6044,7 & 61 & 91 \\
\hline 1936 & 5814,0 & 58 & 96 \\
\hline 1937 & 5375,0 & 54 & 92 \\
\hline 1938 & 6807,0 & 68 & 127 \\
\hline
\end{tabular}




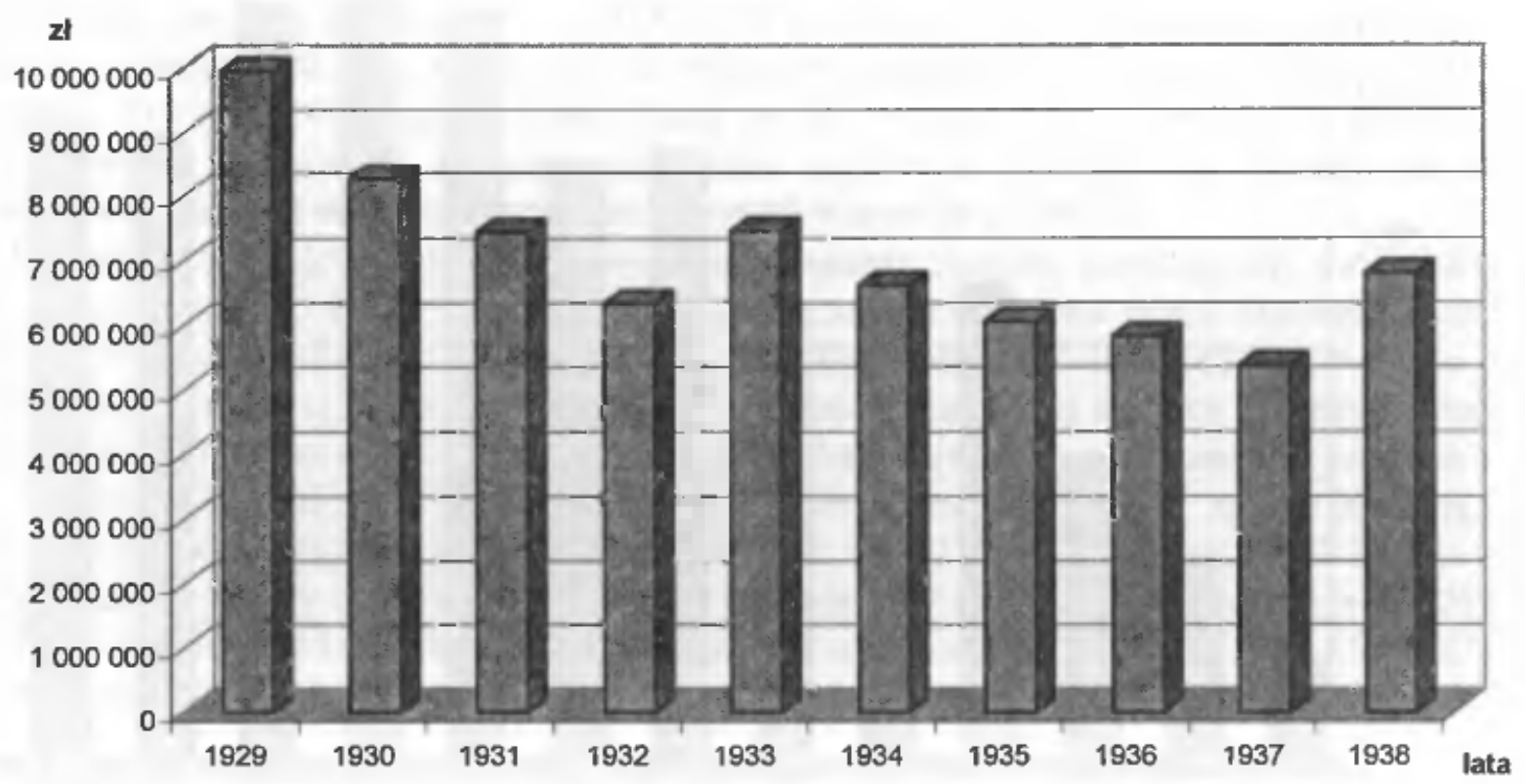

Ryc. 11. Przychody z działalności „Polsko-szwajcarskiej fabryki czekolady Suchard S.A.” w latach 1929-1938

Nagradzana medalami na targach zagranicznych (m.in. Grand Prix Paris), firma od początku intensywnie ogłaszała się w czasopismach i wydawnictwach adresowych, poszerzając dzięki temu $\mathrm{z}$ roku na rok swoje rynki zbytu. Już pierwszy rok działania zakończyła zyskiem (tab.11, ryc.12), wypłacając 5\% dywidendy. W kolejnych latach 1930-31, mimo kryzysu, w przeciwieństwie do firmy A. Piaseckiego, spółka utrzymywała na wysokim poziomie nakłady inwestycyjne, m.in. uruchomiła produkcję szeregu tańszych artykułów, przystosowując się w ten sposób do zwiększonej konkurencji i mniejszej siły nabywczej ludności. Mimo spadku obrotów związanego $\mathrm{z}$ dalszym ubożeniem ludności i koniecznością obniżenia cen, spółka do 1934 osiągała zyski i wypłacała dywidendę, co było ewenementem w skali kraju. Warto zauważyć, że w omawianych latach kryzysu konkurencyjne fabryki wykazywały corocznie straty (np. fabryka A. Piaseckiego - tab.6, ryc.6), a wiele innych przedsiębiorstw ogłosiło upadłość.

Wojna cenowa doprowadziła w 1934r. do dalszych zniżek cen czekolady i tym samym obrotów firmy. Sytuacja finansowa była jednak stabilna, uruchomiono nowy dział cukierkowy, rozpoczęto także produkcję chałwy. W efekcie pod koniec 1934r. roku zatrudnienie osiągnęło poziom prawie 550 osób. 
Tab. 1I. Kształtowanie się zysków (strat) „Polsko-szwajcarskiej fabryki czekolady Suchard S.A." w latach 1928-1938.

\begin{tabular}{|c|c|}
\hline Rok & $\begin{array}{c}\text { Zyski - straty } \\
\text { (tys. zi) }\end{array}$ \\
\hline 1928 & 156,1 \\
\hline 1929 & 341,1 \\
\hline 1930 & 151,0 \\
\hline 1931 & 105,8 \\
\hline 1932 & 61,0 \\
\hline 1933 & 105,2 \\
\hline 1934 & 61,5 \\
\hline 1935 & $-193,4$ \\
\hline 1936 & $-166,5$ \\
\hline 1937 & $-234,8$ \\
\hline 1938 & 109,3 \\
\hline
\end{tabular}

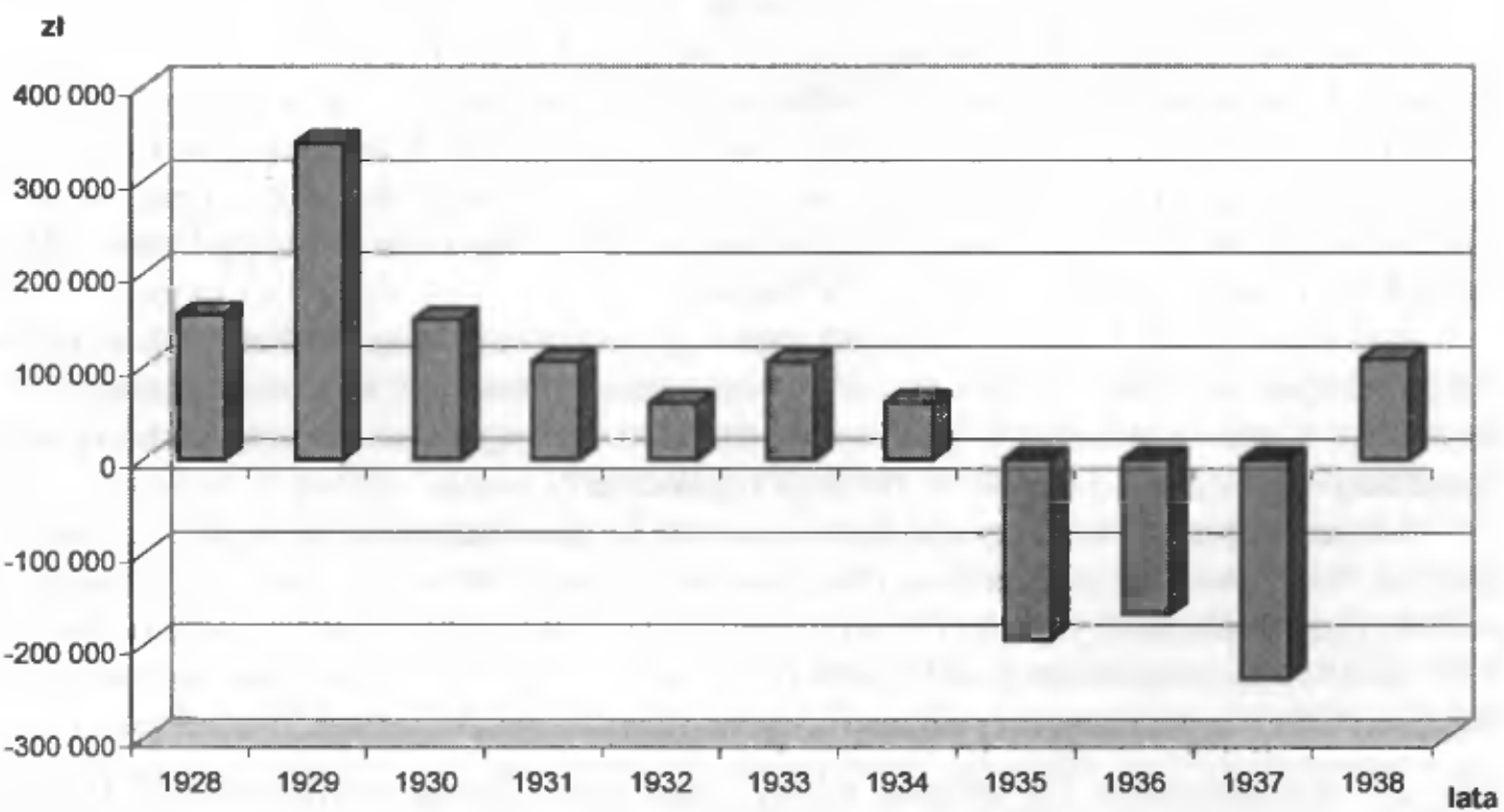

Ryc. 12. Kształtowanie się zysków (strat) „Polsko-szwajcarskiej fabryki czekolady Suchard S.A." w latach 1928-1938.

Niestety także na funkcjonowanie tej firmy znaczący wpływ wywarł kryzys gospodarczy, czego wyrazem był spadek obrotu w 1935r. o dalsze $10 \%$ (tab.10, ryc. 11) i po raz pierwszy w swojej działalności firma zanotowała stratę. Pogorszenie się stanu finansowego firmy, podobnie jak fabryki A. Piaseckiego, było wynikiem: zubożenia konsumentów, podwyżki cła od ziarna $\mathrm{i}$ innych surowców, kontyngentowania przywozu surowców, które 
mogły przekroczyć granicę dopiero po uzyskaniu pozwolenia, co utrudniało negocjacje z zagranicznymi dostawcami, znacznej podwyżki cen tłuszczów; wprowadzenia dodatkowych opłat od thuszczy i syropu kartoflanego; uniemożliwienia eksportu do Gdańska (w związku ze znaczną dewaluacją guldena gdańskiego); bardzo silnej konkurencji w województwach zachodnich, dużych wydatków na urządzenie sklepów w Warszawie i Lodzi, zwiększonych kosztów reklamy w związku z uruchomieniem działu cukierkowego oraz spadku (o 50\%) sprzedaży bezpośrednio z samochodów, przy takich samych kosztach ich utrzymania.

Trudną sytuację finansową firmy pogłębił 8-dniowy strajk załogi w marcu 1936r. i konieczność podwyżki wynagrodzeń o 3-7\%. Równocześnie zaznaczał się też brak ziarna kakaowego i konieczność kupowania go z puli niekontygentowej po cenach o $20 \%$ wyż szych oraz ogólny wzrost cen surowców, przy utrzymujących się kosztach zbytu. Konieczne było zlikwidowanie jednego sklepu w Lodzi, ze względów propagandowych zdecydowano się na urządzenie dwóch nowych sklepów w Warszawie, przy ul. Marszałkowskiej i Nowy Świat (chociaż wszystkie sklepy przynosiły straty). Również w tym czasie nastappił dalszy spadek sprzedaży bezpośredniej z samochodów.

Kolejny, tym razem 6-tygodniowy, strajk robotników na początku 1937r. spowodował przerwanie produkcji i był jedną z przyczyn dalszego spadku obrotów (o $8 \%$ w stosunku do roku poprzedniego). Należy jednak podkreślić, że strajk miał swoje podstawy, gdyż płace w "Suchardzie” należały do najniższych w tej branży. Dzięki podpisaniu układu zbiorowego (m.in. kolejna podwyżka pensji o $10 \%$ ) w 1938r. nie było przerw w produkcji. Zaowocowało to wzrostem obrotów o ok. $25 \%$. Uruchomiono nowy dział proszków i olejków do pieczenia, którego rozwój zapowiadał się pomyślnie. W czasie okupacji grożąc wywiezieniem urządzeń do Wiednia władze Generalnej Guberni faktycznie przejęły firmę, rejestrując w 1943 r. nową spółkę i obejmując 99\% akcji.

Podobnie jak w fabryce A.Piaseckiego i „Kryształ”, w „Suchardzie” już w połowie 1945r. ruszyła normalna produkcja. W 1946r. zakład zatrudniał 346 osób, w tym 298 robotników. Firma została upaństwowiona (musiano zrezygnować ze szwajcarskiej nazwy i produkcji licencyjnej) i weszła w skład ZPC „Wawel”.

Mimo trudnej sytuacji gospodarczej w 1935r. powstała kolejna spółka cukiernicza (przy ul. Kolejowej 12) pod nazwą „Helvetia, fabryka wyrobów czekoladowych i wafli” Do produkcji uźywała maszyny parowej o mocy $50 \mathrm{KM}$ i silników elektrycznych o mocy 120 KM. W 1938 r. zatrudniała średnio 200 robotników. W 1938r. zmieniono nazwę na „Helia”. Od początku działalności przynosiła zyski. (tab. 12, ryc.13).

Tab. 12. Kształtowanie się zysków spółki „Helvetia, fabryka wyrobów czekoladowych i wafli" w latach 1934-1938.

\begin{tabular}{|c|c|}
\hline Okres (rok) & Zyski (w tys. $\mathbf{z l})$ \\
\hline $11.07 .1934-31.12 .1935$ & 8,80 \\
\hline 1936 & 8,20 \\
\hline 1937 & 7,90 \\
\hline 1938 & 10,00 \\
\hline
\end{tabular}




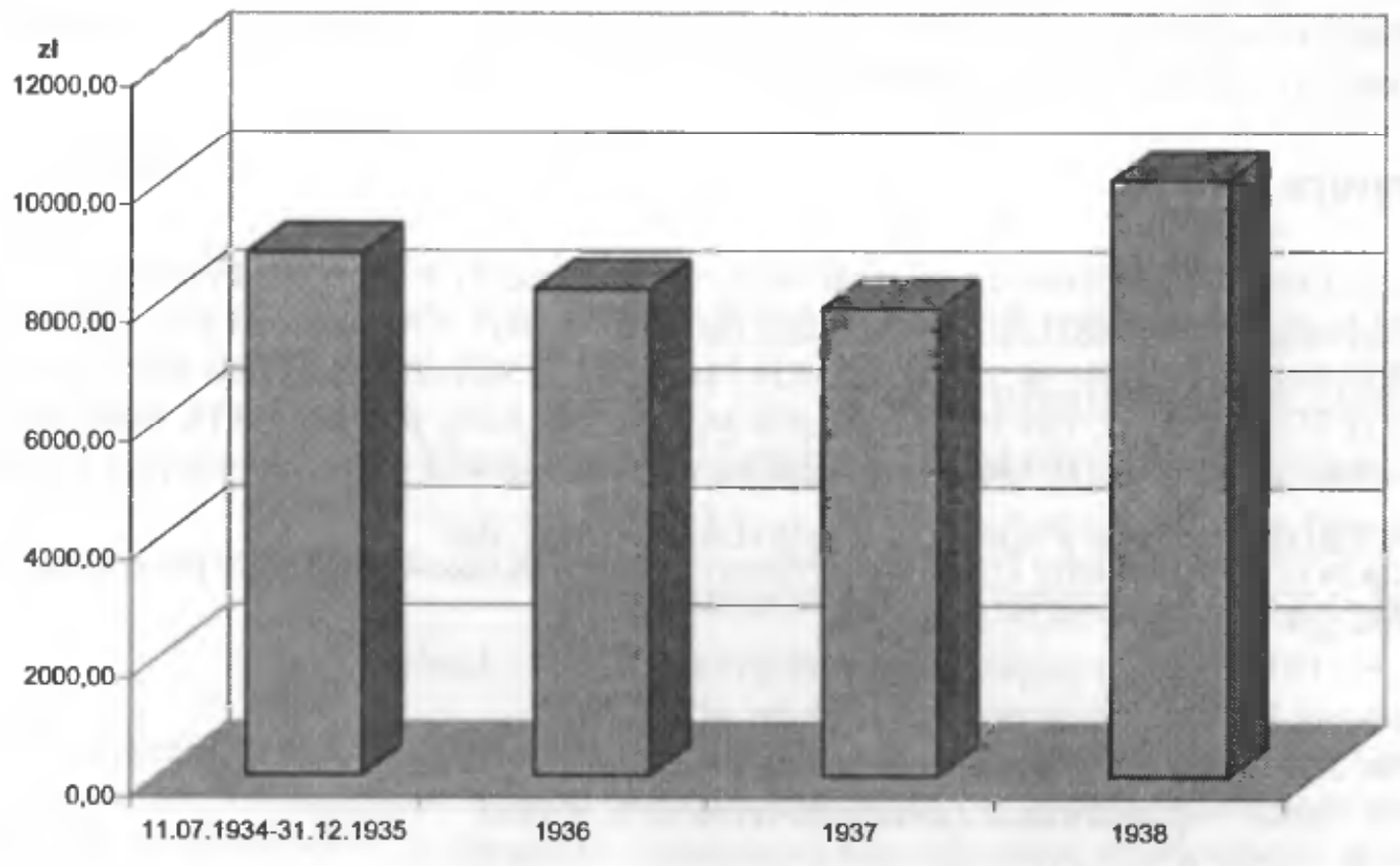

Ryc. 13. Kształtowanie się zysków spółki „Helvetia, fabryka wyrobów czekoladowych i wafli" w latach 1934-1938.

W latach okupacji władze niemieckie ustanowiły zarządcę komisarycznego. Po wojnie spółka na krótko (w latach 1947-1949), wróciła z powrotem w ręce prywatne, następnie została zlikwidowana, a jej majątek przejęty przez państwo.

Podsumowując należy zaznaczyć, że mimo funkcjonowania kilku większych fabryk cukierniczych, tradycje przedwojenne krakowskiego przemysłu cukierniczego związane sa przede wszystkim z osobą Adama Piaseckiego, który w 1910 roku rozpoczął działalność fabryczną $w$ tej branży. Niewątpliwie przełomowym był rok 1920, kiedy powstała na bazie jego przedsiębiorstwa powstała spółka akcyjna, która dzięki znacznym inwestycjom w nieruchomości i w środki produkcji, wykorzystując sprzyjającą koniunkturę gospodarczą, znacznie poszerzyła swoje rynki zbytu. Na podkreślenie zasługuje także działalność szwajcarskiej spółki „Suchard”, która choć powstała w późniejszym okresie (1925r.), dzięki kapitałowi zagranicznemu i dostępowi do know-how rozwijała się dynamiczniej i po względem przychodów oraz wielkości produkcji już w latach przewyższyła fabrykę A. Piaseckiego. $\mathrm{Na}$ funkcjonowanie analizowanych firm znaczący wpływ wywarł wielki kryzys gospodarczy, przy czym najlepiej w tym okresie radziła sobie polsko-szwajcarska firma „Suchard”, która zasilana była kapitałowo przez koncern szwajcarski. Ze względu na brak kapitału obrotowego w wystarczającej wysokości spółce „A. Piasecki” trudniej było przetrwać lata kryzysu, niemniej podjęta działania mające na celu obniżenie kosztów produkcji i zmiany asortymentowe (w kierunku produkcji tańszych wyrobów), przyniosły zadowalające efekty. W latach okupacji wysiłek zarządów firm skierowany był na niedopuszczeniu do całkowitego przejęcia przez Niemców lub likwidacji przedsiębiorstw. $\mathrm{Na}$ kształtowanie się przychodów i zysków w tym okresie decydujący wpływ miały działania 
okupanta regulujące funkcjonowanie rynku. Po zakończeniu wojny w 4 omawianych przedsiębiorstwach niemal natychmiast rozpoczęto produkcję, stopniowo w Il połowie lat 40. zostały one przejęte przez państwo.

\section{Literatura i źródla}

Akta Archiwum Państwowego w Krakowie, sygn. Piasecki 85P- 92P; Pischinger-1;. RH Helvetia (Helia) RH 392 (BX 210); Helia-1, 2; RH Kryształ RH 450 (A IX 226); RH 341 (B IV 182); Kryształ-1,2; RH Piasecki RH 325 (B I 204), RH 430 (A II 103), RH 71 (B V 252); RH Pischinger RH 367 (B VIII 425), RH 381 (B IX 494); RH Suchard RH 332 (B II 213); sygn. Suchard-1,2; Wawel-1,2; Zjedn. Przemysłu Cukierniczego - 1

Ankieta przemysłowa Izby Handlowo-Przemysłowej w Krakowie o stanie przemysłu w jej okręgu w 1926 r., 1928, Kraków

Bujak F., 1917, Rozwój gospodarczy Galicyi (1772-1914). Lwów

Ilustrowany Kurier Codzienny, nr 312, z dn. 10.11.1935

Kaliński J., Landau Z., 1998, Gospodarka Polski w XX w., Warszawa

Kartki z historii, opracowanie z okazji 50-lecia ZPC Wawel

Kortus B., 1968, Kraków jako ośrodek przemysłowy, Kraków

Kotewicz R., 1981, Z dziejów przemystu Krakowa w latach 1918-1939, Kraków

Ksiega adresowa Polski (wraz z w.m. Gdańskiem) dla handlu, przemystu, rzemiosta i rolnictwa, 1928, Warszawa

Malopolskie spólki akcyjne - Księga informacyjno-adresowa, 1922, Kraków

Polski stownik biograficzny, t.XXV, 1980, Wrocław-Warszawa-Kraków-Gdańsk

Polski przemyst $i$ handel - Rynek Polski, Warszawa 1930

Przemysł i Handel, nr $28 \mathrm{z}$ dn. 18.VIII.1921, Warszawa

Przemysł Polski, nr 2, czerwiec 1935, Warszawa

Przewodnik przemysłu i handlu polskiego, 1928, rocznik II, Warszawa

Rocznik polskiego przemysłu i handlu, 1930, 1932, 1934, 1936, 1938

Rocznik informacyjny o spółkach akcyjnych w Polsce, 1929, Warszawa

Spółki akcyjne w Polsce, rocznik drugi 1922/23, Poznań

Spółki akcyjne w Polsce, rocznik trzeci, 1928, Poznań-Warszawa

Weber A., 1970, Geneza i rozwój przemystu cukierniczego w Krakowie (do roku 1914), [w:] Rozwój przemysłu rolno-spożyczego na ziemiach polskich w XIX i XX wieku, Poznań

Życie gospodarcze w okregu krakowskiej Izby Przemystowo-Handlowej 1850-1930, 1930, Kraków 